\title{
KARAKTERISTIK FISIK DAN SENSORIS ES KRIM KACANG MERAH (Phaseolus vulgaris L.) DENGAN PENAMBAHAN TEPUNG UMBI GEMBILI (Dioscorea esculenta L.) SEBAGAI PENSTABIL
}

Physical and Sensory Characteristics of Red Bean (Phaseolus vulgaris L.) Ice Cream with Addition of Gembili Bulbs (Dioscorea esculenta L.) Flour as Stabilizer

\author{
Cicilia Nuryati $^{1) *}$, Anang Mohammad Legowo ${ }^{1)}$, Nurwantoro Nurwantoro ${ }^{1)}$ \\ ${ }^{1)}$ Teknologi Pangan, Fakultas Peternakan dan Pertanian, Universitas Diponegoro \\ Jalan Prof. Soedarto, S.H. Tembalang, Semarang, 50275 \\ *Korespondensi Penulis: cicilia.nuryati@gmail.com
}

\begin{abstract}
Gembili tubers are Dioscoreaceae plants which contain mucus which is water soluble polysaccharide $(13.42 \% \mathrm{db}$ ), able to bind materials and form gels and is glucomannan (Harijono et al., 2010; Prabowo et al., 2014). Gembili tubers can be used as a stabilizer, thickener, and also gelling agent in ice cream products because of this content. This research aims to determine the effect of added gembili tuber flour with different concentrations on overrun, melting speed, total solids, and hedonic quality of red bean ice cream. The material used is red bean porridge, fresh cow's milk, granulated sugar, whipped cream, egg yolks, water, and gembili tuber flour. The experimental design used was a Completely Randomized Design (CRD) with 5 treatments and 4 replications with a formulation of adding gembili tuber flour concentration of $0 \%, 2 \%, 4 \%, 6 \%, 8 \%$. Analysis of the data used is the Analysis of Variants (ANOVA) at a significance level of 5\%. The results showed that the addition of different concentrations of gembili tuber flour to peanut ice cream had a significant effect $(P<0.05)$ on overrun, melting speed, and total solids, as well as texture, taste and thickness characteristics but did not significantly affect the color, aroma, and favorite overalls. The best treatment of added gembili tuber flour as a stabilizer of red bean ice cream is $0.4 \%$.
\end{abstract}

Keywords: gembili tubers, hedonics, ice cream, kidney beans, overrun

\section{PENDAHULUAN}

Es krim merupakan produk olahan beku yang mengandung emulsi lemak dengan tekstur lembut, daya leleh di mulut serta memiliki rasa manis yang umumnya disukai oleh anak-anak maupun orang dewasa. Kandungan gizi es krim berasal dari bahan baku yang digunakan dan mempengaruhi kualitas es krim yang diperoleh (Haryanti \& Zueni, 2015). Daya serat sebagai salah satu gizi yang dapat memberikan sumbangan seimbang mengingat pentingnya pangan yang mengandung serat dapat memperlancar sistem pencernaan manusia.

Serat yang terdapat dalam kacangkacangan pada umumnya didominasi oleh serat tak larut, misalnya selulosa, hemiselulosa, dan lignin (Santoso, 2011).
Kacang merah sebagai salah satu jenis kacang-kacangan yang memiliki kandungan protein nabati tinggi serta serat pangan yang tinggi (24,9\% dalam $100 \mathrm{~g})$, dapat dimanfaatkan dalam pengolahan pangan salah satunya adalah sebagai bahan pembuatan es krim (Simanungkalit et al., 2016). Pembuatan es krim melalui proses pencampuran, pembekuan dan pengadukan bahan baku, pemanis dan penstabil (Mahdiana et al., 2015). Es krim yang berkualitas baik dipengaruhi oleh bahan baku dan penstabil sebagai bahan pengental yang dapat mengikat lemak, air dan juga udara sehingga bersifat stabil. Umumnya bahan penstabil yang digunakan adalah Carboxymethyl Cellulose (CMC), gelatin, karagenan, gum arab dan pektin (Effendi \& Hamzah, 2017). Namun, 
karena sifatnya sangat mempengaruhi kualitas es krim, harga bahan penstabil tersebut cukup mahal sehingga diperlukan adanya penstabil lain yang bersifat polisakarida, salah satunya adalah tepung umbi gembili.

Umbi gembili (Dioscorea esculenta L.) memiliki serat pangan yang bersifat polisakarida larut air (PLA) yang dapat dimanfaatkan dalam hal viskositas, stabilitas, tekstur dan penampilan. PLA kelompok Dioscorea ini mengandung polisakarida terutama glukomanan yang merupakan polisakarida hidrokoloid (Prabowo et al., 2014). Larutan glukomannan sebesar $2 \%$ dalam air dapat membentuk lendir dengan kekentalan sama dengan larutan gum arab 4\%. Hal ini akan mempengaruhi kualitas kestabilan es krim dengan penggunaan bahan penstabil yang bersifat polisakarida larut air (Prabowo et al., 2014).

Oleh karena itu, pengolahan es krim kacang merah dengan penambahan tepung umbi gembili sebagai penstabil adalah salah satu cara pemanfaatan pangan lokal sebagai inovasi produk pangan. Akan tetapi karakteristik fisik dan sensoris es krim dengan penggunaan penstabil berupa tepung umbi gembili belum diketahui sehingga perlu dilakukan penelitian. Produk es krim ini dapat dijadikan sebagai diversifikasi pangan.

\section{METODE PENELITIAN}

\section{Alat dan Bahan}

Alat yang digunakan untuk membuat tepung umbi gembili adalah grinder, pisau, oven, dan ayakan. Alat yang digunakan dalam membuat es krim adalah refrigerator, ice cream maker, freezer, oven dan seperangkat alat dapur. Alat yang digunakan dalam analisis fisik dan sensori es krim adalah cawan porselin, oven, desikator, cup palstik dan stopwatch. Bahan yang digunakan dalam pembuatan es krim adalah susu sapi segar, bubur kacang merah, gula, whipping cream, kuning telur, tepung umbi gembili dan air mineral.

\section{Tahapan Penelitian}

\section{Pembuatan Tepung Umbi Gembili}

Tepung umbi gembili mengacu pada penelitian Winarti et al. (2017), diawali dengan umbi gembili dilakukan penyortiran, pengupasan kulit dan selanjutnya dilakukan pencucian menggunakan air bersih. Umbi yang sudah bersih dilakukan pemotongan dengan ukuran sebesar 2-5 mm. Umbi ditimbang berat awal menggunakan neraca analitik dan dilakukan pengeringan menggunakan oven suhu $60^{\circ} \mathrm{C}$ selama 12 jam. Umbi yang telah dioven dilakukan penggilingan menggunakan grinder untuk menghaluskan umbi gembili kemudian dilakukan pengayakan menggunakan ayakan ukuran 80 mesh sehingga diperoleh tepung umbi gembili yang selanjutnya dilakukan formulasi untuk perlakuan es krim yaitu $0 \%, 0,2 \%, 0,4 \%, 0,6 \%$, dan $0,8 \%$.

\section{Pembuatan Es Krim Kacang Merah dengan Penambahan Tepung Umbi Gembili}

Pembuatan es krim kacang merah diawali dengan pembuatan bubur kacang merah, yaitu kacang merah direbus selama \pm 30 menit suhu didih, kemudian dihancurkan dengan blender sampai halus dengan perbandingan kacang merah dan air 1:1/2 hingga membentuk bubur (Simanungkalit et al., 2016) dan dilanjutkan pembuatan es krim. Susu sapi segar dipasteurisasi suhu $72^{\circ} \mathrm{C}$ selama \pm 15 detik, lalu ditutup menggunakan plastik wrap hingga suhunya $30^{\circ} \mathrm{C}$. Pencampuran bahan dilakukan bertahap sesuai formulasi yaitu kuning telur, gula dan air dicampurkan dengan hand mixer sampai halus dan dipasteurisasi suhu $79^{\circ} \mathrm{C}$ selama 25 detik, dibiarkan sampai suhu $30^{\circ} \mathrm{C}$. Pencampuran whipped cream dan bubur kacang merah, dimasukkan susu cair campur kembali hingga homogen dan 
ditambahkan tepung umbi gembili sesuai perlakuan. Adonan homogen tersebut dipindahkan dalam wadah es krim dilanjutkan proses aging selama 10 menit. Adonan dimasukkan ke dalam ice cream maker 30 menit dan terakhir adonan dikemas pada cup dan dimasukkan ke dalam freezer selama 24 jam (Lanusu et al., 2017).

\section{Rancangan Percobaan}

Penelitian ini menggunakan rancangan acak lengkap (RAL) dengan perlakuan variasi konsentrasi tepung umbi gembili. Perlakuan konsentrasi yang ditentukan adalah berdasarkan hasil penelitian pendahuluan untuk mengetahui proporsi penambahan penstabil, sehingga diperoleh beberapa perlakuan variasi tepung umbi gembili, meliputi konsentrasi T0: 0\%; T1: 0,2\%; T2: 0,4\%, T3: $0,6 \%$ dan T4 : 0,8\% dari jumlah adonan es krim dengan masing-masing perlakuan mendapat empat kali pengulangan.

Data yang diperoleh dianalisis menggunakan metode uji analysis of varians (ANOVA). Apabila terdapat pengaruh perlakuan nyata maka dilanjutkan dengan menggunakan uji duncan multiple range test (DMRT) dengan taraf signifikansi 5\% untuk mencari perbedaan setiap perlakuan. Sementara untuk data uji hedonik menggunakan uji Kruskal-Wallis dan apabila terdapat pengaruh perlakuan maka dilanjutkan dengan uji Mann Whitney.
Semua analisis data dihitung dengan bantuan komputer program SPSS var. 16 for Windows dan aplikasi Microssoft Excel.

\section{Metode Analisis}

Analisis karakteristik fisik dan sensoris es krim kacang merah dengan penambahan tepung umbi gembili menggunakan metode pengembangan volume untuk nilai overrun (Ahmad et al., 2012), waktu lelehan dengan penghitungan waktu leleh es krim pada suhu ruang (Hubeis, 1995), dan uji total padatan dengan pengukuran kadar air es krim (BSN, 2013). Uji sensoris es krim kacang merah dengan penambahan tepung umbi gembili dilakukan dengan memberikan es krim kepada 25 panelis untuk mengetahui daya terima es krim (BSN, 2006; Setyaningsih et al., 2010). Parameter yang digunakan dalam uji sensoris adalah kesukaan warna, aroma, rasa, tekstur, kekentalan. Skala mutu hedonik dengan skor 1-5 berturut-turut menyatakan sangat tidak suka, tidak suka, biasa saja, suka, dan sangat suka.

\section{HASIL DAN PEMBAHASAN}

\section{Nilai Overrun, Waktu Leleh dan Total Padatan Es Krim Kacang Merah}

Es krim kacang merah dengan penambahan tepung umbi gembili memberikan perngaruh terhadap nilai overrun, total padatan dan waktu leleh es

Tabel 1. Nilai overrun, waktu leleh, dan total padatan pada es krim kacang merah dengan penambahan tepung umbi gembili

\begin{tabular}{lccc}
\hline Perlakuan & Overrun & Waktu leleh & Total padatan \\
\hline T0 $(0 \%)$ & $24,21 \pm 0,32^{\mathrm{d}}$ & $13,57 \pm 0,85^{\mathrm{c}}$ & $32,25 \pm 0,50^{\mathrm{c}}$ \\
T1 $(0,2 \%)$ & $26,47 \pm 0,37^{\mathrm{b}}$ & $14,00 \pm 0,60^{\mathrm{c}}$ & $33,25 \pm 0,64^{\mathrm{b}}$ \\
T2 $(0,4 \%)$ & $27,49 \pm 0,72^{\mathrm{a}}$ & $15,33 \pm 0,92^{\mathrm{b}}$ & $33,87 \pm 0,62^{\mathrm{ab}}$ \\
T3 $(0,6 \%)$ & $26,43 \pm 0,55^{\mathrm{b}}$ & $16,08 \pm 0,88^{\mathrm{b}}$ & $34,37 \pm 0,25^{\mathrm{a}}$ \\
T4 $(0,8 \%)$ & $25,40 \pm 0,38^{\mathrm{c}}$ & $17,39 \pm 0,88^{\mathrm{a}}$ & $34,25 \pm 0,86^{\mathrm{a}}$ \\
\hline
\end{tabular}

Keterangan: - Data ditampilkan sebagai nilai rerata dari 4 ulangan \pm standar deviasi

- Superscript yang berbeda pada kolom yang sama menunjukkan perbedaan nyata $(\alpha<0,05)$

- T0, T1, T2, T3 dan T4 = es krim dengan konsentrasi tepung umbi gembili: $0 \%, 0,2 \%, 0,4 \%$, $0,6 \%$ dan $0,8 \%$ 
krim. Nilai overrun, waktu leleh dan total padatan es krim kacang dengan penambahan tepung umbi gembili ditunjukkan pada Tabel 1.

Es krim kacang merah dengan penambahan tepung umbi gembili memberikan pengaruh nyata $(\mathrm{P}<0,05)$ terhadap nilai overrun, waktu leleh, dan total padatan. Kenaikan nilai overrun es krim dipengaruhi oleh penambahan penstabil berupa tepung umbi gembili yang dapat memperangkap udara selama agitasi. Menurut Saputri et al. (2015), penstabil dalam pembuatan es krim akan menstabilkan kondisi terperangkapnya udara dalam adonan sehingga dapat meningkatkan nilai overrun. Penstabil juga akan memberikan waktu leleh es krim yang lebih lama karena bersifat mampu mengikat air bebas dan dalam es krim. Sesuai dengan pendapat Cakrawati \& Kusumah (2016) yang menyatakan bahwa umbi gembili mengandung polisakarida larut air memiliki sifat hidrokoloid berupa glukomannan yang dapat mengikat air bebas dan memperangkap udara dengan menahan kondisi pembekuan air semakin kecil, sehingga menghasilkan padatan es krim yang semakin tinggi viskositasnya dan berpengaruh terhadap waktu leleh es krim yang semakin lama.

Penambahan stabilizer dari tepung umbi gembili mempengaruhi nilai overrun dan waktu leleh es krim yang semakin lama karena meningkatkan viskositas es krim. Hal ini sependapat dengan Aulia et al. (2019) yang menyatakan bahwa waktu pelelehan es krim dipengaruhi oleh viskositas adonan dimana semakin kental bahan akan mempengaruhi jumlah udara yang masuk dalam adonan sehingga berpengaruh terhadap nilai overrun yang mengakibatkan waktu pelelehan semakin lama seiring dengan tingkat viskositas es krim. Proses pembekuan dan homogenisasi juga dapat mempengaruhi naik turunnya nilai overrun es krim yang diperoleh (Masykuri et al., 2012). Tepung umbi gembili memiliki karakteristik dapat menyerap air, meningkatkan viskositas dan kepadatan adonan sehingga mempengaruhi nilai total padatan dan waktu pelelehan. Hal ini sesuai dengan Pratiwi et al. (2016) yang menyatakan bahwa tepung umbi gembili mengandung karbohidrat, protein dan pati yang mana sifat dari karakteristik tersebut dapat meningkatkan rendemen dan adonan tinggi serta mempengaruhi karakteristik fisik dan kimia hasil olahan.

Tepung umbi gembili bersifat hidrokoloid jenis glukomannan yang mampu menyerap air dalam bahan. Hal ini sangat baik dalam pembuatan es krim karena meningkatkan nilai total padatan serta lama waktu pelelehan. Sesuai dengan pendapat Prabowo et al. (2014) yang menyatakan bahwa umbi gembili merupakan jenis umbian yang mengandung PLA (polisakarida larut air) yang bersifat hidrokoloid, hal ini akan mempengaruhi kesediaan air dalam bahan yang semakin diserap oleh sifat PLA sehingga meningkatkan total padatan. Glukomannan tepung umbi gembili mampu meningkatkan total padatan es krim kacang merah sesuai perlakuan. Hal ini sesuai dengan pendapat Tatirat et al. (2012) yang menyatakan bahwa glukomannan memiliki sifat unik yang tersusun oleh unit D-manossa dan Dglukosa yang dapat menyerap air dengan intensitas sangat tinggi sehingga mempengaruhi nilai viskositas dan total padatan bahan. Perlakuan T2 menghasilkan nilai overrun terbaik, T3 dan T4 menghasilkan total padatan sesuai standar SNI (1995) yaitu minimal 34\%, sedangkan nilai waktu lelehan terbaik terdapat pada T4.

\section{Karakteristik Mutu Sensoris Es Krim Kacang Merah}

Hasil sensoris es krim kacang merah dengan penambahan tepung umbi gembili sebagai penstabil terdiri dari 6 atribut yaitu warna, aroma, rasa, tekstur, kekentalan, dan overall kesukaan. Penilaian sensori hedonik es krim kacang merah terhadap 
penambahan tepung umbi gembili memberikan pengaruh tingkat kesukaan yang berbeda masing-masing panelis, aroma dan overall kesukaan, namun memberikan pengaruh nyata terhadap hedonik rasa, tekstur dan kekentalan.

\section{Nilai Hedonik Warna Es Krim Kacang Merah}

Penambahan tepung umbi gembili tidak berpengaruh nyata terhadap hedonik warna. Nilai hedonik warna es krim kacang merah dengan penambahan tepung umbi gembili ditunjukkan pada Tabel 2 . Warna es krim kacang merah cenderung merah pucat yang dihasilkan oleh bahan utama kacang merah $(0,2-0,8 \%)$ dalam pembuatannya (Tabel 2). Hal ini sesuai dengan pendapat Putri et al. (2016) yang menyatakan bahwa pigmen antosianin dari kacang merah mampu memberikan warna yang merah alami pada es krim. Warna merah pucat dari hasil es krim kacang merah dapat diindikasikan bahwa proses perebusan mempengaruhi penurunan intensitas warna alaminya. Hal ini sependapat dengan Fitriani \& Awaliyah (2015) yang menyatakan bahwa antosianin adalah zat warna alami yang bersifat polar dan memiliki tingkat kestabilan relatif menurun terhadap suhu tinggi karena terjadi kerusakan gugus kromofor pigmen sehingga menyebabkan pemucatan warna.

\section{Nilai Hedonik Aroma pada Es Krim Kacang Merah}

Nilai hedonik aroma pada es krim kacang merah yang paling diterima adalah es krim kacang merah dengan perlakuan tepung umbi gembili $0,4 \%$. Berdasarkan Tabel 2, aroma es krim yang dihasilkan dipengaruhi oleh penggunaan bahan baku kacang merah. Sesuai pendapat Esvandiari et al. (2010) yang menyatakan bahwa kacang merah mengandung enzim lipoksigenase yang apabila bereaksi dengan lemak akan menghasilkan senyawa yang khas yaitu etil-fenil-keton dan memberikan aroma khas dengan sedikit langu. Faktor bahan baku yang digunakan juga mempengaruhi aroma yang dihasilkan. Rachmawanti \& Handajani (2011) menjelaskan bawa umumnya es krim menggunakan bahan dasar susu dan gula mempengaruhi aroma es krim yang dihasilkan, komposisi lemak dalam proporsi yang tepat akan mempengaruhi pembentukan flavor yang menghasilkan aroma pada es krim.

\section{Nilai Hedonik Rasa pada Es Krim Kacang Merah}

Aroma es krim kacang merah didominasi oleh kacang merah sebagai bahan penambah cita rasanya, pengaruh penambahan cita rasa kacang merah dan

Tabel 2. Nilai hedonik warna es krim kacang merah dengan penambahan tepung umbi gembili

\begin{tabular}{|c|c|c|c|c|c|c|}
\hline \multirow[b]{2}{*}{ Perlakuan } & \multicolumn{6}{|c|}{ Nilai hedonik } \\
\hline & Warna** & Aroma** & Rasa* & Tekstur* & Kekentalan* & $\begin{array}{c}\text { Overall } \\
\text { kesukaan** }\end{array}$ \\
\hline T0 $(0 \%)$ & $3,96 \pm 0,88^{a}$ & $3,72 \pm 1,17$ & $3,32 \pm 0,80^{\mathrm{b}}$ & $3,20 \pm 0,81^{\mathrm{b}}$ & $3,72 \pm 0,84^{b}$ & $3,64 \pm 1,15$ \\
\hline $\mathrm{T} 1(0,2 \%)$ & $3,51 \pm 1,50$ & $3,68 \pm 1,18$ & $4,04 \pm 0,97^{\mathrm{a}}$ & $3,40 \pm 1,00^{\mathrm{b}}$ & $3,32 \pm 0,80^{b}$ & $3,24 \pm 1,21$ \\
\hline $\mathrm{T} 2(0,4 \%)$ & $3,80 \pm 1,04$ & $4,24 \pm 0,87$ & $3,72 \pm 0,89^{\mathrm{ab}}$ & $3,96 \pm 0,93^{a}$ & $4,00 \pm 0,95^{\mathrm{a}}$ & $3,56 \pm 1,12$ \\
\hline T3 $(0,6 \%)$ & $4,08 \pm 0,75$ & $3,92 \pm 0,95$ & $3,88 \pm 0,88^{a}$ & $4,08 \pm 0,75^{\mathrm{a}}$ & $3,80 \pm 0,81^{\mathrm{a}}$ & $4,12 \pm 1,09$ \\
\hline $\mathrm{T} 4(0,8 \%)$ & $3,24 \pm 1,39$ & $3,52 \pm 1,04$ & $3,48 \pm 0,87^{\mathrm{ab}}$ & $4,20 \pm 0,86^{\mathrm{a}}$ & $3,44 \pm 0,82^{a b}$ & $3,60 \pm 0,91$ \\
\hline
\end{tabular}

Keterangan: - Data ditampilkan sebagai nilai rerata dari 4 ulangan \pm standar deviasi

- *Superscript yang berbeda pada kolom yang sama menunjukkan perbedaan nyata $(\alpha<0,05)$

- ** Jika tidak terdapat superscript pada kolom yang sama menunjukkan tidak berbeda nyata

- T0, T1, T2, T3 dan T4 = es krim dengan konsentrasi tepung umbi gembili: $0 \%, 0,2 \%, 0,4 \%, 0,6 \%$ dan $0,8 \%$ 
perlakuan tepung umbi gembili sebagai penstabil es krim ditunjukkan pada Tabel 2.

Es krim kacang merah memiliki rasa khas susu karena berbahan dasar susu dan dengan penambahan whipping cream. Menurut Masykuri et al. (2012), rasa khas susu yang dihasilkan oleh es krim kacang merah karena dipengaruhi oleh adanya penambahan whipping cream. Rasa es krim juga cenderung khas kacang merah karena menggunakan bahan kacang merah. Hal ini sesuai dengan pendapat Nurlita et al. (2017) yang menyatakan bahwa dalam kacang merah terdapat serat dan rasa khas kacang yang kuat sehingga dapat mempengaruhi kesukaan cita rasanya (Tabel 2). Penambahan tepung umbi gembili dengan proporsi tepat memberikan rasa yang pas pada es krim. Hal ini sesuai dengan pendapat Siswati et al. (2019) yang menyatakan bahwa umbi gembili memiliki senyawa bioaktif seperti terpenoid, fenolik, steroid, dan flavonoid dengan jumlah yang sangat bervariasi yang berpengaruh terhadap karakteristik rasa yang khas umbi pada hasil produk. Perlakuan terbaik penambahan tepung umbi gembili terhadap hedonik rasa es krim kacang merah adalah $0,4 \%$.

\section{Nilai Hedonik Tekstur pada Es Krim Kacang Merah}

Perlakuan penambahan tepung umbi gembili berpengaruh terhadap hedonik tekstur es krim kacang merah. Nilai hedonik tekstur pada es krim kacang merah ditunjukkan pada Tabel 2. Tekstur lembut es krim dipengaruhi oleh bahan baku kacang merah yang mengandung protein dan lemak. Hal ini sesuai dengan pendapat Arbuckle (1986) yang menyatakan bahwa udara yang terperangkap oleh rantai pendek protein, lemak dan juga laktosa akan menghasilkan nilai overrun semakin tinggi sehingga berdampak pada tekstur yang lembut. Perlakuan tepung umbi gembili mempengaruhi tekstur es krim dari lembut dan semakin kuat seiring penambahannya, karena sifat dari polisakaridanya (Tabel 2). Hal ini sependapat dengan Prabowo et al. (2014) yang menyatakan bahwa tepung umbi gembili mengandung PLA (polisakarida larut air) yang bersifat hidrokoloid, yang akan menghidrasi air secara alami dengan ikatan hidrogen pada molekul polisakaridanya sehingga air bebas tidak mengkristal, polisakarida yang semakin banyak meningkatkan daya cegah mobilitas air dalam bahan sehingga mengentalkan dan membentuk tekstur kuat. Tekstur berhubungan dengan total padatan dan nilai overrun es krim. Hal ini sesuai dengan pendapat Putri et al. (2016) yang menyatakan bahwa besarnya nilai total padatan es krim mempengaruhi kecilnya rongga udara dalam es krim, ini berarti bahwa overrun akan semakin menurun, overrun yang menurun mengakibatkan tekstur es krim yang kasar dan kuat.

\section{Nilai Hedonik Kekentalan pada Es Krim Kacang Merah}

Nilai hedonik kekentalan es krim kacang merah dipengaruhi oleh perlakuan penambahan tepung umbi gembili sebagai penstabil. Nilai hedonik kekentalan es krim kacang merah ditunjukkan pada Tabel 2. Perlakuan tepung umbi gembili memberikan pengaruh terhadap tingkat kekentalan es krim kacang merah, karena kandungan glukomannannya. Hal ini sesuai dengan pendapat Fidyasari et al. (2017) yang menyatakan bahwa PLA pada umbi gembili mengandung polisakarida utama glukomannan yang bersifat hemiselulosa dan bersifat mengikat kuat dengan air, polisakarida ini akan bersifat hidrokoloid kuat sehingga membentuk kestabilan emulsi, pembentukan gel serta meningkatkan kekentalan bahan. Perlakuan penambahan tepung umbi gembili yang tinggi mempengaruhi tingkat kesukaan pada es krim yang semakin menurun diindikasikan karena terlalu padat dan umbi gembili mengandung pati. Hal 
ini sesuai dengan pendapat Pratiwi et al. (2016) yang menyatakan bahwa umbi gembili mengandung amilopektin yang lebih banyak dibandingkan amilosa, kandungan amilosa dan amilopektin ini mempengaruhi tingkat kerekatan bahan dimana semakin tinggi amilopektin akan semakin merekat kuat membentuk viskositas yang tinggi.

\section{Nilai Overall Kesukaan pada Es Krim Kacang Merah}

Perlakuan es krim kacang merah dengan penambahan tepung umbi gembili tidak berpengaruh nyata terhadap nilai overall es krim (Tabel 2). Penambahan tepung umbi gembili tidak mempengaruhi kecenderungan kenaikan maupun penurunan tingkat kesukaan, karena faktor kesukaan merupakan penilaian secara acak panelis yang umumnya dipengaruhi oleh sifatnya. Menurut Winarno (1992), tingkat kesukaan terhadap produk tertentu dipengaruhi oleh panelis dan bersifat relatif bergantung dengan selera pribadi panelis juga dengan sifat sensoris masingmasing panelis dengan penentuan umumnya secara visual. Penggunaan bahan baku kacang merah juga tidak mempengaruhi tingkat kesukaan keseluruhan es krim yang diperoleh. Hal ini sependapat dengan Putri et al. (2016) yang menyatakan bahwa selain komponen cita rasa, kesukaan panelis dipengaruhi oleh bahan-bahan baku yang digunakan dan timbulnya perasaan panelis setelah menelan makanan.

\section{KESIMPULAN}

Es krim kacang merah
penambahan tepung umbi
mempengaruhi nilai overrun dari
peningkatan awal menjadi turun,
peningkatan lama waktu pelelehan serta
total padatan yang semakin naik.
Perbedaan konsentrasi tepung umbi
gembili juga memberikan pengaruh
terhadap mutu hedonik yaitu rasa, tekstur
yang halus, kekentalan yang semakin

padat, dan overall kesukaan, namun tidak berpengaruh terhadap warna dan aroma es krim kacang merah. Penambahan tepung umbi gembili sebagai penstabil es krim kacang merah yang optimal adalah 0,4\%, yaitu dengan karakteristik es krim yang cukup padat, nilai overrun relatif tinggi dengan waktu lelehan yang sesuai standar.

\section{DAFTAR PUSTAKA}

Achmad, F., Nurwantoro, \& Mulyani, S. 2012. Daya kembang, total padatan, waktu pelelehan, dan kesukaan es krim fermentasi menggunakan starter Saccharomyces cereviceae. Animal Agriculture Journal, 1 (2): 65-76.

Arbuckle, W.S. 1986. Ice Cream. The AVI Publishing Company. Westport, Connecticut.

Aulia, S., Rizqiati, H., \& Nurwantoro. 2019. Pengaruh substitusi kefir terhadap sifat fisik, total khamir dan hedonik es krim. Jurnal Teknologi Pangan, 3 (2): 192-198.

Badan Standardisasi Nasional (BSN). 1995. SNI 1995. 01-3713-1995. Es Krim. Dewan Standardisasi Nasional Indonesia, Jakarta.

Cakrawati, D., \& Kusumah, M.A. 2016. Pengaruh penambahan CMC sebagai senyawa penstabil terhadap yoghurt tepung gembili. Jurnal Agrointek, 10 (2): 76-84.

Effendi, R., \& Hamzah, F.H. 2017. Variasi rasio bahan penstabil CMC (carboxy methyl cellulose) dan gum arab terhadap mutu velva alpukat (Parsea americana mill.). Jurnal Faperta, 4 (2): 1-15.

Esvandiari, M., Sholihin, H., \& Suyatna, A. 2010. Studi kinerja adsorbsi arang aktif bentonit pada aroma susu kacang kedelai. Jurnal Sains dan Teknologi Kimia, 1 (2): 135-149

Fidyasari, A., Sari, R.M., \& Raharjo, S.J. 2017. Identifikasi komponen kimia pada umbi bentul (Colocasia esculenta L. Schoot) sebagai pangan fungsional. Jurnal Amerta Nutrition, 1 (1): 14-21. 
Fitriani, F., \& Awaliyah, N. 2015. Pengaruh suhu ekstraksi dan lama pemanasan terhadap stabilitas pigmen antosianin dan karatenoid. Jurnal Buletin AlRibaath, 12 (1): 35-43.

Harijono, T.E., Sunarharum, W.B., \& Rakhmita, I.S. 2010. Karakteristik kimia ekstrak polisakarida larut air dari umbi gembili (Dioscorea esculenta) yang ditunaskan. Jurnal Teknologi Pertanian, 11 (3): 162-169.

Haryanti, N., \& Zueni, A. 2015. Identifikasi mutu fisik, kimia, dan organoleptik es krim daging kulit manggis (Garcinia mangostana L.) dengan variasi susu krim. Jurnal Agritepa, 2 (1): 143-156.

Lanusu, A.D., Surtijono, S.E., Karisoh, L.C.M., \& Sondakh, E.H.B. 2017. Sifat organoleptik es krim dengan penambahan ubi jalar ungu (Ipomea batatas L.). Jurnal Zootek, 37 (2): 474482.

Mahdiana, I., Purwadi, P., \& Jaya, F. 2017. Pengaruh kombinasi penambahan sari wortel (Daucus carota L.) dan tepung hunkwee pada es krim kefir terhadap kualitas fisik dan kimia es krim kefir. Jurnal Ilmu dan Teknologi Hasil Ternak, 10 (1): 1-8.

Masykuri, Y.B., Pramono, \& Ardilia, D. 2012. Resistensi pelelehan, over-run, dan tingkat kesukaan es krim vanilla yang terbuat dari bahan utama kombinasi krim susu dan santan kelapa. Jurnal Aplikasi Teknologi Pangan, 1 (3): 7882.

Nurlita, N., \& Hermanto, H. 2017. Pengaruh penambahan tepung kacang merah (Phaseolus vulgaris L.) dan tepung labu kuning (Cucurbita moschata) terhadap penilaian organoleptik dan nilai gizi biskuit. Jurnal Sains dan Teknologi Pangan, 2 (3): 562-574.

Prabowo, A.Y., Estiasih, T., \& Purwantiningrum, I. 2014. Umbi gembili (Dioscorea esculenta L.) sebagai bahan pangan mengandung senyawa bioaktif: Kajian pustaka. Jurnal Pangan dan Agroindustri, 2 (3): 129-135.
Pratiwi, K.I., Zaini, M.A., \& Nazaruddin, N. 2016. Pengaruh konsentrasi gel buah okra (Abelmoschus esculentus L.) terhadap mutu es krim campuran susu sapi dan susu kedelai. Jurnal Pro Food, 2 (2): 131-139.

Putri, D., Wulandari, Y., \& Suhartati, N. 2016. Karakteristik fisikokimia dan sensoris es krim kacang merah (Phaseolus vulgaris L.) dengan variasi penambahan bubuk kelopak bunga rosella. Jurnal Teknologi dan Industri Pangan, 1 (1): 47-53.

Putri, K.D., Zaini, M.A., \& Kisworo, D. 2017. Pengaruh rasio susu full cream dengan jagung manis (Zea mays saccharata) terhadap nilai gizi, sifat fisik dan organoleptik es krim. Jurnal Pro Food, 1 (1): 15-23.

Rachmawanti, D., \& Handajani, S. 2011. Es krim ubi jalar ungu (Ipomoea batatas): Tinjauan sifat sensoris, fisik, kimia, dan aktivitas antioksidannya. Jurnal Teknologi Hasil Pertanian, 4 (2): 94103.

Santoso, I.A. 2011. Serat pangan (dietary fiber) dan manfaatnya bagi kesehatan. Jurnal Magistra, 23 (75): 3540.

Saputri, O.M., Tjaronosari, \& Wijanarka, A. 2015. Variasi pencampuran tepung labu kuning sebagai bahan penstabil es krim ditinjau dari sifat fisik, organoleptik dan kadar beta karoten. Jurnal Nutrisia, 17 (2): 101-107.

Simanungkalit, H., Indriyani, \& Ulyarti. 2016. Kajian pembuatan es krim dengan penambahan kacang merah (Phaseolus vulgaris L.). Jurnal Penelitian Universitas Jambi : Seri Sains, 18 (1): 20-26.

Siswati, O.D., Bintoro, V.P., \& Nurwantoro, N. 2019. Karakteristik es krim ubi jalar ungu (Ipomoea batatas var ayamurasaki) dengan penambahan tepung umbi gembili (Dioscorea esculenta L.) sebagai bahan penstabil. Jurnal Teknologi Pangan, 3 (1): 121126. 
Tatirat, O., Charoenrein, S., \& Kerr, W.L. 2012. Physicochemical properties of extrusion-modified konjac glucomannan. Journal Carbohydrate Polym, 87 (2): 1545-1551.

Winarno, F.G. 1992. Kimia Pangan Gizi. Gramedia Pustaka Utama, Jakarta.

Winarti, S., Susiloningsih, E.K.B., \& Fasroh, Y.Z. 2017. Karakteristik mie kering dengan substitusi tepung gembili dan penambahan plastiziser GMS (gliserol mono stearat). Jurnal Agrointek, 11 (2): $53-62$. 